\title{
ARTÍCULO 12
}

"Seguro voluntario

En materia de pensiones, el interesado podrá ser admitido al seguro voluntario de un Estado Parte, incluso cuando esté obligatoriamente sometido a la legislación de otro Estado Parte, siempre que, con anterioridad, haya estado sometido a la legislación del primer Estado Parte por el hecho o como consecuencia del ejercicio de una actividad como trabajador dependiente o no dependiente y a condición de que dicha acumulación esté admitida en la legislación del primer Estado Parte”.

\section{MAR ALARCÓN CASTELLANOS}

Profesora Titular de Derecho del Trabajo y Seguridad Social Universidad Rey Juan Carlos

\section{POR PROBLEMAS TÉCNICOS ESTE ARCHIVO ESTÁ TEMPORALMENTE DESHABILITADO. DISCULPEN LAS MOLESTIAS}

